\title{
INTERPRETAÇÃO QUANTITATIVA DE CAMPOS DE POTENCIAL ESPONTÂNEO NA PERFILAGEM GEOFÍSICA DE POÇOS
}

\author{
Glaucia Cecotto Dotti \\ Orientador: Dr. Carlos Alberto Mendonça (IAG/USP) \\ 72 p. - Dissertação (Mestrado) - Defesa 16.09.2008
}

\begin{abstract}
RESUMO. Potenciais elétricos espontâneos (PE) são frequentemente medidos na geofísica de poço para identificar camadas permeáveis e a composição dos fluidos em reservatórios (petróleo) e aquíferos (água subterrânea). 0 potencial medido resulta de dois processos. 0 primeiro é devido ao gradiente de concentração (potencial de junção liquida) existente entre soluções justapostas no ambiente do poço; o segundo é devido ao fenômeno da eletrocinese (potencial eletrocinético) observado quando um fluido infiltra por um meio poroso. 0 potencial eletrocinético é aproximadamente dez vezes menor que o potencial de junção líquida e frequentemente é desconsiderado quando a concentração de água de formação é avaliada. Em muitos casos, no entanto, existem evidências de que a contribuição do potencial eletrocinético é expressiva, sugerindo que se devidamente identificado, ele poderia ser utilizado tanto para melhorar as estimativas de concentração quanto para fornecer informações referentes às propriedades hidráulicas da formação. Métodos existentes para avaliar a permeabilidade das rochas em condições de poço são em geral complexos e a possibilidade de prever essas propriedades a partir de dados de perfilagem seria muito importante na avaliação de uma formação. Esta pesquisa propõe um procedimento para isolar parâmetros característicos do potencial de junção líquida e eletrocinético através da formulação de um problema inverso, a partir de um conjunto de dados compostos por repetidas medições (PE) para lamas de diferentes concentrações salinas. Este procedimento realça seletivamente a contribuição dos potenciais de junção líquida e eletrocinético no potencial resultante e permite estimar os parâmetros desconhecidos (queda de pressão e resistividade da água) em termos de um problema inverso. A viabilidade da técnica proposta é discutida com base em simulações numéricas e resultados preliminares de um experimento em escala realizado em laboratório.
\end{abstract}

ABSTRACT. Spontaneous electric potentials (SP) are often measured in borehole geophysics to identify permeable layers and the fluid contents in petroleum reservoirs and ground water aquifers. In borehole conditions two processes generated the measured electric fields. The first one is related to gradient concentration of juxtaposed solutions (liquid junction potential); the second to electrokinetic effects (streaming potential) observable when a fluid infiltrates a porous media. The streaming potential is around ten times smaller than the liquid junction potential and often is disregarded when water concentration is evaluated. In many cases, however, there are evidences that electrokinetic contribution is expressive, suggesting that if properly accounted for, it could be used either to improve concentration estimates as to give some insight about the formation hydraulic properties. Existing methods to evaluate rock permeability in borehole conditions are in general troublesome and the possibility to predict it from routine well logging data certainly will be important to evaluate a rock formation. This research proposes a procedure to isolate key parameters in the liquid junction and electrokinetic potentials by applying an inverse problem formulation to a data set composed by repeating SP measurements for different drilling mud salt concentrations. This procedure selectively enhances the liquid-junction and the electrokinetic contributions in the resulting potential and allows to estimate the unknown parameters (pressure drop and pore water resistivity) in terms of an inverse problem. The feasibility of the proposed technique is discussed based on numerical simulations and preliminarily laboratory results with a model scale experiment. 